\title{
Chloride Penetration Depth in Silica Fume Concrete
}

\author{
Gladis Camarini, Paulo Sérgio Bardella, and Denise Cristina Barbosa
}

\begin{abstract}
This study was performed to evaluate chloride ion penetration depths in concrete produced with high early strength Portland cement with and without silica fume replacement ( $10 \%$ by mass). Two curing procedures were used to produce precast structures curing: air and steam curing at 60 ${ }^{\circ} \mathrm{C}$. Chloride ion depths were measured at 90 days by spraying a solution of $0.1 \mathrm{~N} \mathrm{AgNO3}$ at specimen surfaces. The results showed that Chloride ion penetration depth in silica fume concrete was diminished.
\end{abstract}

Index Terms-Chloride ions, silica fume, steam curing, concrete.

\section{INTRODUCTION}

Durability of concrete structures depends, among other factors, on the thickness, compacting and permeability of concrete surface. Concrete surface is a barrier for the entrance of water and deleterious agents into the concrete. These deleterious agents, such as carbon gas, chloride ions, sulfates, among others, begin the damage processes and reduce the life cycle of the concrete structure.

It is generally agreed that the ingress of chloride ions into concrete leads, in many structures, to long-term deterioration. In other words, chloride permeability of the concrete is one such intrinsic property of the concrete that needs to be assessed independently, especially in the design and construction of structures to be built in a salt-laden environment. The chloride-induced corrosion of reinforcing steel is the major cause for the premature deterioration and degradation of majority of concrete structures built in salt-laden environment, and therefore, the chloride permeability has been recognized to be a critical intrinsic property of the concrete. The chloride-induced corrosion of reinforcing steel manifest through cracking, spalling, and delamination of the concrete cover, which eventually leads to the direct exposure of the reinforcing steel to aggressive environment [1].

The chloride ions penetration in concrete occurs through the capillary suction, diffusion (transport of ions caused by differences in ion concentration), and in some cases for the ionic migration. The diffusion of the chloride ions in concrete is always followed by chemical and physical reactions with the hydrated compounds of Portland cement that modify the

Manuscript received May 19, 2013; revised July 21, 2013. This work was supported in part by the National Counsel of Technological ans Scientific Development - CNPq.

Gladis Camarini is with School of Civil Engineering, Architecture and Urban Design at University of Campinas, UNICAMP. Campinas, São Paulo Brazil, Av. Albert Einstein, 951, POBox 6021, CEP: 13083-852, Campinas, SP (e-mail: gcamarini@gmail.com, camarini@fec.unicamp.br).

Paulo Sérgio Bardella is with Londrina Filadelfia Universitaire Center, Londrina, Paraná, Brazil (e-mail: pbardela@uol.com.br ).

Denise Cristina Barbosa is with University of Campinas, Campinas, São Paulo, Brazil. porous structure of the concrete [2], [3].

Chloride ions may exist in concrete due to the mixing water, aggregates, seawater and polluted soil. When these chloride ions reach the steel bar, they are adsorbed by its surface promoting the hydration of the metallic ions, forming a soluble complex of $\mathrm{FeCl}_{2}$. At a certain distance of the electrode formed by the reinforcement this compound is broken and the chloride ion is free to transport more ferrous ions. Thus, the chloride ions acts freely as a catalysis reaction; in other words, a single chloride ion can be reused again, giving continuity to the reaction. In that way, small amounts of chloride ions can be responsible for great part of corrosion [4] [5]. The corrosion reactions in reinforced concrete structures for chloride are shown as follows [5]:

$$
\begin{gathered}
\mathrm{Fe}^{+2}+2 \mathrm{Cl}^{-} \rightarrow \mathrm{FeCl}_{2} \\
\mathrm{FeCl}_{2}+2 \mathrm{H}_{2} \mathrm{O} \rightarrow \mathrm{Fe}(\mathrm{OH})_{2}+2 \mathrm{Cl}^{-} \\
6 \mathrm{FeCl}_{2}+\mathrm{O}_{2}+6 \mathrm{H}_{2} \mathrm{O} \rightarrow 2 \mathrm{Fe}_{3} \mathrm{O}_{4}+12 \mathrm{H}^{+}+12 \mathrm{Cl}^{-}
\end{gathered}
$$

Concentration of chloride ions around the steel reinforcement is not enough to cause corrosion. Reaction with steel reinforcement is continued if water and oxygen are available in concrete pores. Thus, the propagation stage of steel corrosion is followed by the growth of radial cracks from the steel bar, which will eventually lead to spalling of concrete surface [1].

Silica fume replacement (by part of the cement mass) contributes to obtain a concrete with high compressive strength, decrease the porosity, increase the abrasion resistance and the chemical corrosion resistance, increase too the adhesion between different concrete surfaces and improve the adherence between concrete and steel bars, among other advantages [6].

Silica fume produces chemical and physical effects in the microstructure of the concrete. The chemical effect occurs because of pozzolanic reactions between the amorphous silica $\left(\mathrm{SiO}_{2}\right)$ from mineral addition and the calcium hydroxide $\left(\mathrm{Ca}(\mathrm{OH})_{2}\right)$ produced by the cement hydration reactions forming calcium silicate hydrated (C-S-H). Moreover, the physical effect of the finer grains allows denser packing within the cement and reduces the wall effect in the transition zone between the pastes and the aggregates. Thus, the physical action of the silica fume provides a denser, more homogeneous and uniform paste [7]-[10].

It must be emphasized that correct practical procedures, including adequate curing, are essential to produce a durable concrete structure. Deterioration of a concrete structure will depend on the porous structure of the concrete surface, as well as the amount and the continuity of the capillary pores. An adequate curing provides a concrete with denser and compact structure, increasing its resistance to aggressive 
agents of the environment [11], [12].

The work of Güneyisi et al., [1] showed that initial curing conditions had a substantial influence on the rate of chloride penetration for the plain and especially blended cement concretes. Lack of proper initial curing considerably aggravated the chloride ion penetration through the concretes but the degree in the rate of increment of the chloride penetration depended mainly on the $\mathrm{w} / \mathrm{c}$ ratio of the concrete mixture, type of cement used in the production of concrete, and the immersion period in the salt solution.

The aim of this experimental study was to evaluate the effect of the concrete curing in depth of chloride ions penetration. It were used two curing procedures: curing in air and steam curing at a maximum temperature of $60^{\circ} \mathrm{C}$. These two curing procedures are usually used in production of precast structures in Brazil. The concretes were produced with high-early strength Portland cement with and without silica fume replacement ( $10 \%$ by mass of cement) for each curing procedure used. These materials are usually used to produce precast concrete elements

\section{EXPERIMENTAL PROCEDURE}

\section{A. Materials}

Cement used was a high early strength Portland cement, named CP V ARI, from a Brazilian source, corresponding to ASTM Type III cement. The chemical composition and physical properties are presented in Table I.

Natural sand (specific gravity of $2630 \mathrm{~kg} / \mathrm{m}^{3}$ ) and crushed stone (specific gravity of $2960 \mathrm{~kg} / \mathrm{m}^{3}$ ) with maximum size of $19 \mathrm{~mm}$ were used in concrete production (Fig. 1) (Fig. 2).

Silica fume was a Microssílica Elkem 920-U, a densified silica fume.

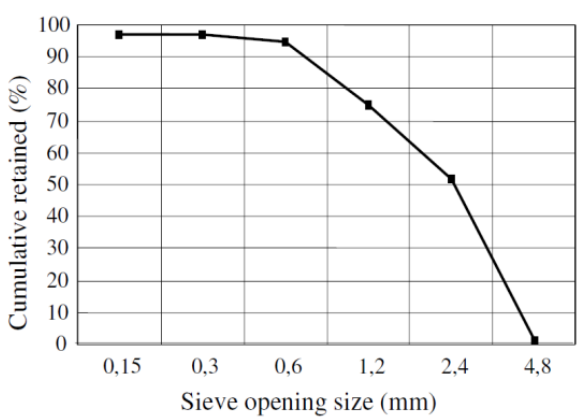

Fig. 1. Fine aggregate grading.

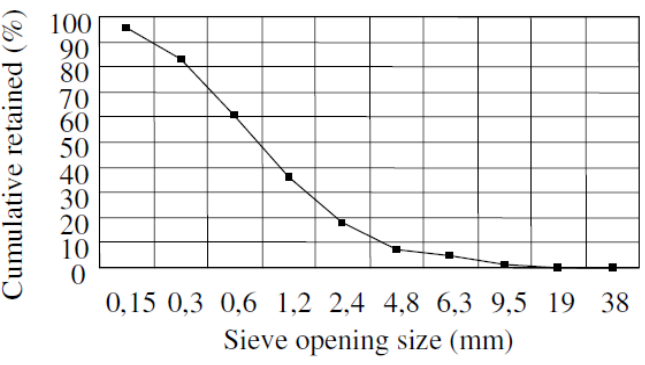

Fig. 2. Coarse aggregate grading.

Superplasticizer was a polymer ether carboxylic-based, without chloride, developed for the precast and prestressed concrete industry. The amount of additive used in concretes with and without silica fume is shown in Table II. The additive was added to the mixing water, following the producer instructions.

\section{B. Concrete Mixture Proportions}

The mix materials were measured by mass and the water/binder ratio was kept constant at 0,42 (water/binder ratio $=0,42)$ (Table II). All concretes had the same consistency (slump).

Materials were mechanically mixed. After mixing, the specimens were cast as cylinders of $100 \mathrm{~mm}$ diameter and $200 \mathrm{~mm}$ height and were nominated (Table III).

TABLE I: CHEMICAL COMPOSITION AND PHYSICAL PROPERTIES OF CEMENT

\begin{tabular}{lc}
\hline \multicolumn{1}{c}{ Cement } & $\begin{array}{c}\text { CP V ARI } \\
\text { PLUS }\end{array}$ \\
\hline Clinker (\% in mass of cement) & 90,6 \\
Gypsum (\% the cement in mass) & 6,0 \\
Carbonatic Mat. (\% the cement in & 3,4 \\
mass) & \\
$\mathrm{C}_{3} \mathrm{~S}$ & 56,7 \\
$\mathrm{C}_{2} \mathrm{~S}$ & 11,7 \\
$\mathrm{C}_{3} \mathrm{~A}$ & 8,1 \\
$\mathrm{C}_{4} \mathrm{AF}$ & 9,5 \\
Initial setting (minutes) & 115 \\
Final setting (minutes) & 200 \\
Blaine Fineness $\left(\mathrm{cm}^{2} / \mathrm{g}\right)$ & 4650 \\
Specific gravity $\left(\mathrm{g} / \mathrm{cm}^{3}\right)$ & 3,090 \\
\hline \hline
\end{tabular}

TABLE II: MIXTURE PROPORTIONS OF CONCRETES (KG/M³)

\begin{tabular}{lcc}
\hline \hline Mix Proportion & $\begin{array}{c}\text { Current } \\
\text { Concrete }\end{array}$ & $\begin{array}{c}\text { Silica fume } \\
\text { Concrete }\end{array}$ \\
\hline Cement & 398,40 & 358,60 \\
Silica Fume & - & 39,80 \\
River Sand & 796,80 & 796,80 \\
Coarse Agregate & 1195,20 & 1195,20 \\
Water & 167,33 & 167,33 \\
Superplasticizers & 1435 & 2390 \\
(ml/m $\mathbf{m}^{\mathbf{3}}$ & & \\
Slump test (mm) & $20 \pm 5$ & $20 \pm 5$ \\
\hline \hline
\end{tabular}

TABLE III: SYMBOLS OF THE PRODUCED CONCRETES

\begin{tabular}{lcc}
\hline \hline Symbol & Curing conditions & $\begin{array}{c}\text { Silica fume } \\
\text { Replacement }\end{array}$ \\
\hline ARI-AMB & Air curing & No \\
ARI-60 & Steam curing & No \\
ARI-SIL-AMB & Air curing & Yes \\
ARI-SIL-60 & Steam curing & Yes \\
\hline \hline
\end{tabular}

\section{Curing Conditions}

Chloride ions penetration depths were obtained in specimens submitted to two curing procedures: curing in air and steam curing $\left(60^{\circ} \mathrm{C}\right)$.

After demolding (24 hours), specimens cured in air were 
exposed to laboratory conditions at $25^{\circ} \mathrm{C}$ and $65 \%$ relative humidity until the age of testing.

Steam curing followed the curing cycle of Fig. 3 [13], [14] with the following periods:

1) Presteaming period $\left(\mathrm{t}_{0}\right)$ - a delay period between batching and application of steam. It was used a period of 210 min corresponding to the initial setting time for CP V ARI.

2) Temperature rise period $\left(t_{1}\right)$ : the temperature in the curing chamber was increased to $60{ }^{\circ} \mathrm{C}$ at a rate of 20 ${ }^{\circ} \mathrm{C} /$ hour.

3 ) Isothermal period $\left(t_{2}\right)$ : specimens were kept in steaming at constant temperature $\left(60^{\circ} \mathrm{C}\right)$ for 4 hours.

4) Cooling Period $\left(t_{3}\right)$ : the chamber temperature is reduced to the ambient level, not exceeding the rate of 30 ${ }^{\circ} \mathrm{C} /$ hour. The rate of temperature decrease is controlled in order to avoid thermal stresses.

After steam curing the specimens were kept in air at laboratory conditions $\left(25^{\circ} \mathrm{C}\right.$ and $65 \%$ relative humidity) until the age of the test.

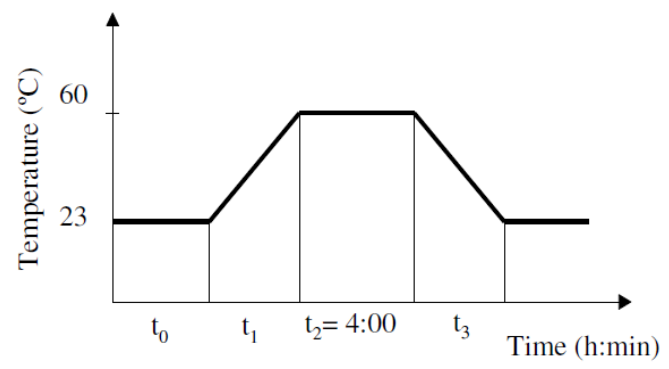

Fig. 3. Steam curing cycle [13], [14].

\section{Chloride Ions Penetration}

Chloride ions penetration depth test was performed at 90 days of age. Starting from this age, the test was made in two stages.

First Stage:

Specimens were kept in a chamber at $50{ }^{\circ} \mathrm{C}$ for 24 hours. After that, the lateral surfaces of the cylinders were sealed so that only the bottom surfaces were in contact with water. This sealing was to prevent solution evaporation from the lateral surfaces. Then, the specimens were submitted to drying/wetting cycles in a solution of $\mathrm{NaCl}$. The solution

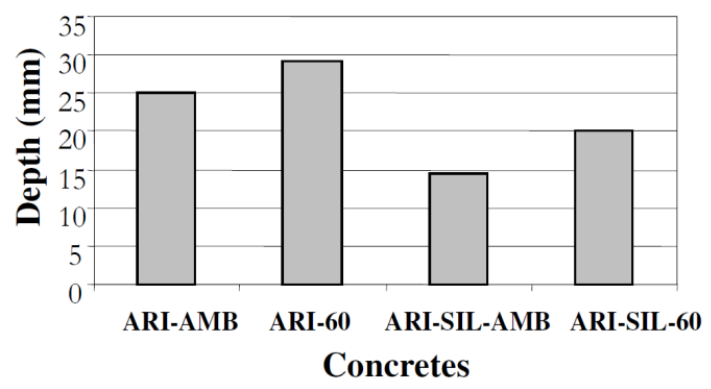

Fig. 3. Chloride ions penetration depth of concretes with and without silica fume replacement

The results for concrete without silica fume submitted to steam curing at $60{ }^{\circ} \mathrm{C}$ showed the highest value of chloride ions penetration. The chloride ions were detected at 29,13 $\mathrm{mm}$ depth. This can be attributed to steam curing procedure that allow the formation of non uniform structure of the concentration varies in function of the attack that it is necessary to provide. Normally, solutions of $\mathrm{NaCl}$ in concentrations from $2 \%$ to $10 \%$ have been used to evaluate the attack from chloride in concrete [15] [16]. In this work it was used a solution of $5 \% \mathrm{NaCl}$ concentration. The specimens are immersed in solution to constant depth of 10 $\mathrm{mm}$. This stage was 48 hours long. After immersion period, specimens were kept in a chamber at $50{ }^{\circ} \mathrm{C}$ for 24 hours, and after they were kept in laboratory conditions for 4 days $\left(25^{\circ} \mathrm{C}\right.$ and $65 \%$ relative humidity). This drying/wetting cycle was eight days long and it was repeated eight times (eight cycles). Four specimens were tested for all concretes and for each curing condition. Fig. 4 represents the drying/wetting cycle.

Second Stage:

After eight cycles, specimens were fractured diametrically and their surfaces were sprayed with a solution of $0,1 \mathrm{~N}$ of silver nitrate $\left(\mathrm{AgNO}_{3}\right)$. This solution was used to determine the penetration depth of free chloride ions [15], [16]. Silver nitrate in contact with free chloride ions reacts forming the silver chloride $(\mathrm{AgCl})$, showing a precipitate of white color. The concrete surfaces where there ares no free chlorides ions show a brown colour. In this way, it becomes possible to make a qualitative measure of the presence of free chloride ions, and measuring the depth of penetration from this colourimetric test.

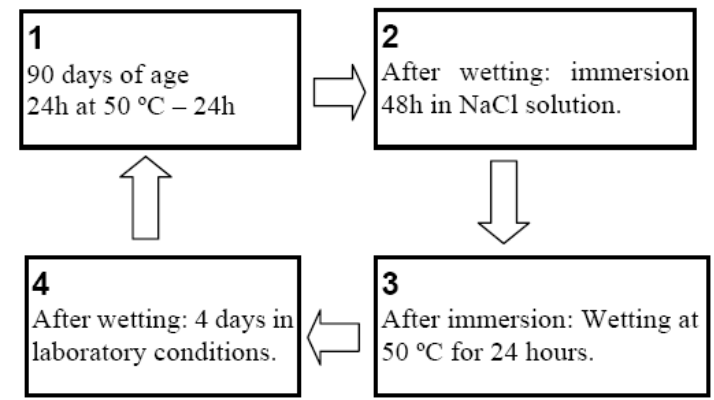

Fig. 4. Drying/Wetting Cycle in chloride solution [17].

\section{RESULTS AND DISCUSSION}

Fig. 3 shows the results of chloride ions penetration depth observed for all concretes studied.

hydration products forming a dense region around the cement particles impeding further hydration of these encapsulated cement grains in the late age, resulting in a more concrete porous structure [14], [10].

However, when cement was replaced by silica fume for both curing conditions (air and steam curing) concrete became more resistant to chloride ions penetration. Silica fume reduced the chloride ions penetrations in concretes submitted to curing in air in $75 \%$, and $45 \%$ in concretes submitted to steam curing. This fact can be related with pozzolanic reaction of silica fume, having a better filling of voids, allowing a lower permeability of concrete and a structure paste more compact [6], [7], [17], [18].

\section{CONCLUSION}

The following conclusions are based on this study of the 
influence of chloride ions penetration depth in concretes with and without silica fume replacement submitted to steam curing and curing in air. This study is important for concrete structures in marine environment, in special those from precast industry.

In both curing conditions (steam curing at $60^{\circ} \mathrm{C}$ and curing in air) silica fume replacement improved the performance of concretes when submitted to aggressive environment with presence of chloride ions.

The use of curing conditions influenced the chloride ions penetrations depth. The steam curing showed the highest results of chloride ions penetrations depths for both concretes with and without silica fume replacement.

Silica fume concretes submitted to steam curing had the worst performance related to chloride ion penetration. In this way, it is suggested to perform tests with other concretes and cements to evaluate the performance in aggressive environments.

\section{ACKNOWLEDGMENT}

This research was carried out at the Faculty of Civil Engineering (DAC-FEC), University of Campinas. The authors thank staff from Laboratory of Construction Materials where the experiments were performed. The authors acknowledge the CNPq National Council of Technological and Scientific Development.

\section{REFERENCES}

[1] E. Güneyisi, T. Özturan, and M. Gesoğlu, "Effect of initial curing on chloride ingress and corrosion resistance characteristics of concretes made with plain and blended cements," Building and Environment, vol. 42, pp. 2676-2685, 2007.

[2] E. P. Nielsen and M. R. Geiker, "Chloride diffusion in partially saturated cementitious material," Cement and Concrete Research, vol. 33 , pp. 133-138, 2003.

[3] E. Güneyisi, T. Özturan, and M. Gesoglu. "A study on reinforcement corrosion and related properties of plain and blended cement concretes under different curing conditions," Cement and Concrete Composites, vol. 27. pp. 449-461, 2005.

[4] A. Rosenberg, C. M. Hansson, and C. Andrade, "Mechanisms of corrosion of steel in concrete," The American Ceramic Society, 1989, pp. 285-313.

[5] K. Thangavel and N. S. Rengaswamy, "Relationship between chloride/hidroxide ratio and corrosion rate of steel in concrete," Cement and Concrete Composites, vol. 20, pp. 283-292, 1998.

[6] G. A. Rao. Investigations on the performance of silica fume-incorporated cement pastes and mortars. Cement and Concrete Research, vol. 33, pp. 1765-1770, 2003.

[7] M. D. Cohen and M. Klitsikas. "Mechanisms of hydration and strength developments in Portland cement composites containing silica fume particles," Indian Concrete Journal, vol. 60, pp. 296-300, 1986.
[8] H. A. Toutanji and Z. Bayasi. "Effect of curing procedures on properties of silica fume concrete," Cement and Concrete Research, vol. 29, pp. 497-501, 1999.

[9] P. C. Aitcin, High Performance Concrete, 1st ed. CRC Press, 1998. $624 \mathrm{p}$.

[10] R. D. Hooton and M. P. Titherington, "Choride resistence of high-performance concretes subjected to accelerated curing," Cement and Concrete Research, vol. 34, pp. 1561-1567, 2004.

[11] A. M. Neville, Properties of Concrete, John Wiley \& Sons, 1996

[12] P. K. Mehta and P. J. M. Monteiro, Concrete: Microstructure, Properties and Materials, McGraw Hill, 2006, pp. 659.

[13] G. Camarini, "Curing Effects on Air Permeability Concrete," Advanced Materials Research, vol. 214, pp. 602-606, 2011.

[14] G. Camarini, "Performance of mixtures of Portland Cement and Blastfurnace Slag Submmitted to Steam Curing," PhD Thesis, University of São Paulo, São Paulo, Brazil, 1995.

[15] M. Arslan, "The effect of permeable formworks with sucker liners on the physical properties of concrete surfaces," Construction and Building Materials, vol. 15, no. 4, pp. 149-156, 2001.

[16] E. Meck and V. Sirivivatinanon, "Field indicator of chloride penetration deph," Cement and Concrete Research, vol. 33, pp. 1113-1117, 2003.

[17] P. S. Bardella and G. Camarini, "Properties of steam cured concretes with silica fume addition," in Proc. of IV Int. ACI/CANMET Conf. on Quality of Concrete Structures and Recent Advances in Concrete Materials and Testing, Olinda, PE, Brazil, pp. 1-15, 2005.

[18] R. Ferreira, H. Carasek, O. Cascudo, and A. Lopes, "Influence of mineral additions on chloride permeability in concrete," in Proc. of $45^{\circ}$ Brazilian Concrete Congress, Vitória, ES, 2003, pp. 1-15.

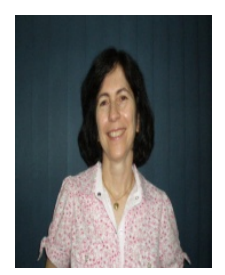

Gladis Camarini is a Civil Engineer and Professor at School of Civil Engineering, Architecture and Urban Design, University of Campinas. She had her Master Degree (1988) and PhDegree (1995) at University of São Paulo. Postdoctoral studies at the Laboratoire des Materiaux et Durabilité des Constructions (LMDC), INSA, Toulouse, France, 1998. Postdoctoral studies at the National Institute for Space Research (INPE, São José dos Campos, Brazil, 2008). Postdoctoral studies at the Institute of Science and Technology del Hormigón (ICITECH), the Polytechnic School of Valencia (UPV) (Valencia, Spain, 2012). She is peer-reviewer of scientific journals indexed on the Journal Citation Reports, national and international journals, Congress and Seminars, and Brazilian Research Foundations. Her research interest are building materials, mineral binders, mortars, industrial and construction wastes, reusing and recycling of materials, concrete, and steam curing.

Paulo Sérgio Bardella is a Civil Engineer and is working as Assistant Professor at University Center Filadélfia (UNIFIL) and Collaborating Assistant Professor at the State University of Londrina (UEL). He developed his Master Degree at University of Campinas (2005) on concrete technology. His PhDegree was also at University of Campinas (2011) on recycling construction and demolition waste. His research interest are concrete durability, constructin and demolition waste, and building construction.

Denise Cristina Barbosa is a Civil Engineer working on building construction. She developed her Master Degree at University of Campinas (2004) on durability of concrete. Her research interest are durability of concrete and building construction. 